\section{俩 Heighten Science P U B L I C A T I O N S Corporation ISSN 2574-0350}

\title{
Rapid Microbial Growth in Reusable Drinking Water Bottles
}

\author{
Hongjun Liu ${ }^{1,2}$ and Qishan Liü ${ }^{3 *}$ \\ ${ }^{1}$ Key Laboratory of Natural Medicine and Immuno-Engineering of Henan Province, Henan \\ University, Kaifeng, Henan 475004, People's Republic of China \\ ${ }^{2}$ AGplus Technologies Pte Ltd, 10 Jalan Besar \#10-06 Sim Lim Tower, Singapore \\ ${ }^{3}$ School of Architecture and the Built Environment, Singapore Polytechnic, 500 Dover Road, \\ Singapore
}

\begin{abstract}
*Address for Correspondence: Qishan Liu School of Architecture and the Built Environment, Singapore Polytechnic, 500 Dover Road, Singapore 139651. Email: liu_qishan@sp.edu.sg

Submitted: 17 August 2017

Approved: 05 October 2017

Published: 06 October 2017

Copyright: @ 2017 Liu Q, et al. This is an open access article distributed under the Creative Commons Attribution License, which permits unrestricted use, distribution, and reproduction in any medium, provided the original work is properly cited.
\end{abstract}

Keywords: Reusable drinking water bottle; Heterotrophic plate count; Bacteria enumeration; Drinking water

\section{Summary}

Bacteria has been known to grow in pipes of water distribution systems and bottled drinking water. Its growth in reusable drinking water bottles is not clear even though they have become more popular and used by children and adults daily everywhere. This study found that there is an extremely high level of bacteria content and a rapid microbial growth in reusable drinking water bottles. The bacteria content tested by heterotrophic plate count (HPC) is in a range of $0-2.4 \times 10^{5} \mathrm{CFU} / \mathrm{mL}$ with an average of about 34,000 bacteria counts $/ \mathrm{ml}$ for bottles used by children and 75,000 bacteria counts/ml for bottles used by adults. Bacteria number can quickly increases to 1-2 million counts/ml in the bottles one day later. Considering the high level of HPC bacteria content in the reusable drinking water bottles, it may be necessary to have some control measures to reduce the bacteria level and to minimize the associated likely health risk of the disease spreading since many people use reusable water bottles every day.

\section{Introduction}

Safe drinking water has always been one of the primary requirements for healthy and sustainable human life. Water is used every day by every single person. However, World Health Organization (WHO) reported that 884 million people do not have access to safe drinking water, and 2.2 million deaths (mainly children) are attributed to diarrhea, which is transmitted through contaminated water, inadequate sanitation or hygiene [1-4]. One of the biggest threats to public health is caused by bacterial pathogen in drinking water, which leads to the outbreaks of diseases such as giardiasis, gastroenteritis, cholera, cryptosporidiosis, etc [5]. Having access to safe drinking water is essential to the health. It has been reported that bacteria will grow in bottled drinking water [6-10]. A population of approximately $10^{2}-10^{5}$ colony forming unit per $\mathrm{ml}(\mathrm{CFU} / \mathrm{ml})$ was found in the mineral water after bottling [8]. Bacteria was also found growing in the pipes of water distribution systems [11-15]. It was found that the average number of heterotrophic plate count (HPC) bacteria in household taps averaged to $3,072 \mathrm{CFU} / \mathrm{ml}$, and the number of HPC bacteria increases dramatically from the distribution system to consumers' tap [13].

Drinking water stored in the reusable water bottles and used for drinking consumption is popular in many parts of the world by either young children or adults. It becomes more popular since the early 21st century as more studies and research about the disadvantages of disposable bottled water were discovered. Reusable water bottle not only saves money for the user in the long run, it is also more environmentally friendly than disposable bottles. Common materials that reusable water bottles are 
made up of are copolyester, polycarbonate, polyethylene, polypropylene, steel and aluminium. However, there is little information available on microbial growth in the reusable drinking water bottle and its associated health risks even it is normally used daily for many months or even years by users. There is direct contact between bottle and hand/mouth or other sources of contamination. This could lead to the growth of bacteria and possibly pathogenic bacteria in the bottles which may pose health risks to people. In this paper, we would like to report the findings from our study about the bacteria level and its growth in reusable drinking water bottles.

\section{Materials and Methods}

\section{Enumeration of bacteria}

The total number of the bacteria in the water was enumerated by heterotrophic plate count according to the Standard Methods for the Examination of Water and Wastewater [16]. Water was analyzed for the bacteria number immediately after it was sampled from the reusable water bottles. R2A agar used for the bacteria cultivation was purchased from Neogen Corporation (Acumedia, Michigan, US). In the enumeration of HPC bacteria, an Eppendorf pipette was used to transfer $0.1 \mathrm{~mL}$ of the water sample onto the R2A agar plate. Disposable L-shaped spreaders were used to spread the water sample onto the plate. Each diluted sample was prepared in triplicate and a series of dilution was conducted for every sample. The plates were then incubated at $37^{\circ} \mathrm{C}$ for two days with the plates always turned upside down. After incubation the colonies on the agar plates were counted for the number of HPC bacteria colonies formed using a Suntex Colony Counter (Suntex, Taiwan). To ensure more accurate estimation of the bacteria, only plates with a countable range of 30 to 300 colonies per plate were counted.

\section{Chlorine analysis}

Free and total chlorine content in the water was analysed by chlorine meter (Palintest ChloroSense, Model CS100, England). Disposable electrodes (sensors) was used for every measurement.

\section{Results}

\section{Bacteria content in reusable drinking water bottles}

The bacteria content was analysed in the reusable drinking water bottles used by children aged from 2 to 7 years old at a childcare centre in Singapore. It is a common practice in Singapore for children or even adults to bring their own drinking water in reusable water bottles for their daily consumption. Boiled tap water is normally used to fill in the bottles. In this test, thirty water samples were collected from the bottles used by children (Figure 1) at around 10:00 AM in the morning, which is about 3-4 hours after the bottles have been filled up, since majority of the children wake up and prepare for school at around 6:00-7:00 AM. In most cases, the water in the bottles would have been consumed a few times. The capacity of the bottles used by children ranges from 0.2 to $1.0 \mathrm{~L}$, and majority of the bottles have a capacity around $350 \mathrm{~mL}$. The material for these bottles is mostly copolyester, polypropylene, or polyethylene. It was found that the average number of heterotrophic bacteria is $3.4 \times 10^{4}\left( \pm 3.0 \times 10^{4}\right)$ $\mathrm{CFU} / \mathrm{mL}$ and ranged from 0 to $1.4 \times 10^{5} \mathrm{CFU} / \mathrm{mL}$. It can be seen from the data that bacteria content in the bottles has a wide range and big standard error (Figure 3 ). However, only one sample among the thirty water samples tested, equivalent to $3 \%$, has a bacteria content below $500 \mathrm{CFU} / \mathrm{mL}$.

A testing of bacteria content in the reusable drinking water bottles used by students at a tertiary education institute was also conducted. Thirty water samples were collected from the bottles (Figure 3) at around 10:00 AM in the morning, which is also about 3-4 hours after the bottles have been filled up with water. The majority 


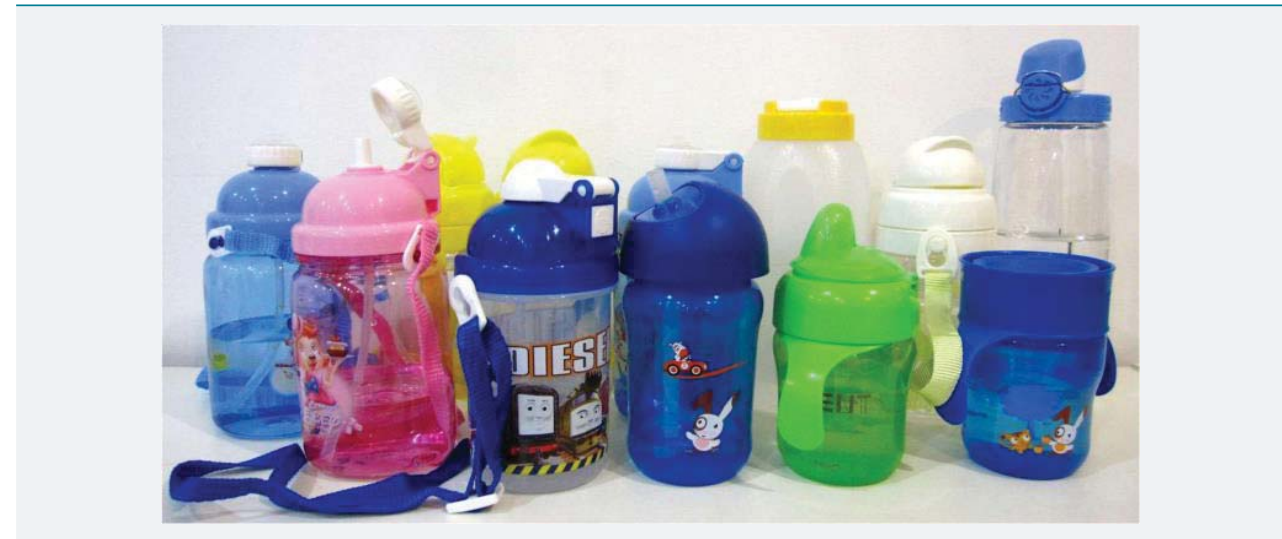

Figure 1: Photo of reusable drinking water bottles at a childcare centre taken for bacteria content testing.

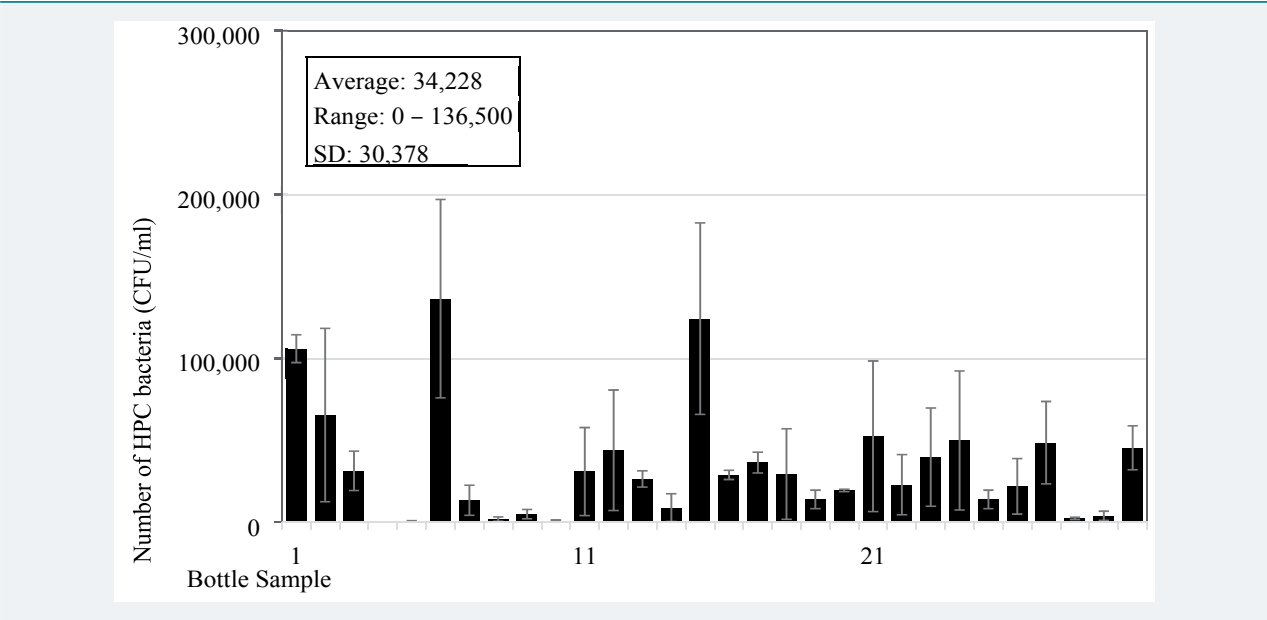

Figure 2: HPC bacteria number in drinking water bottles sampled at a childcare centre.

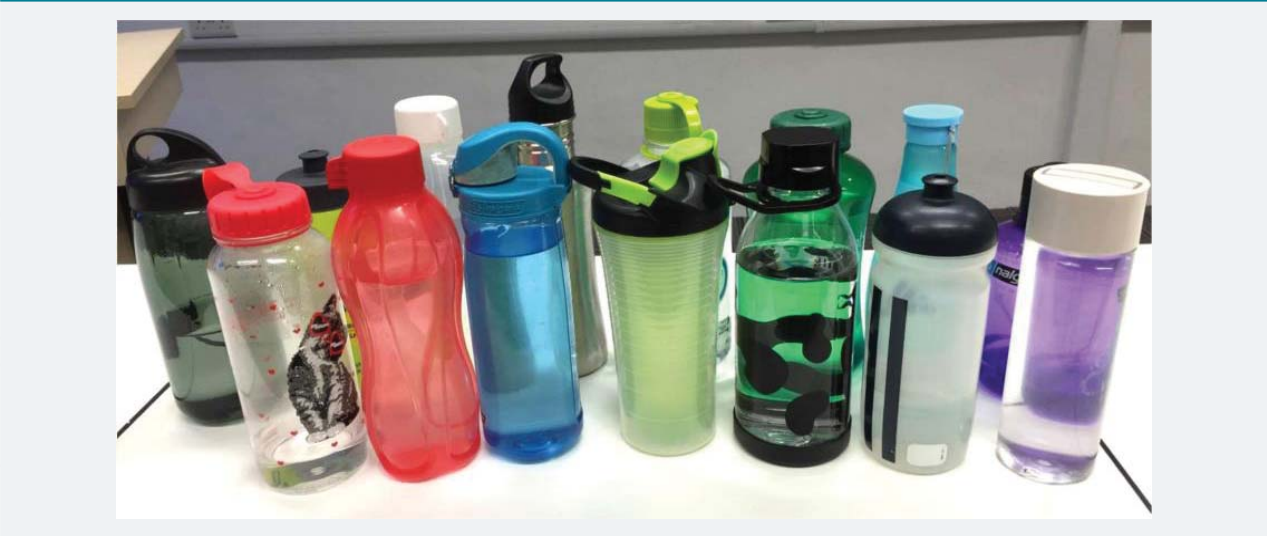

Figure 3: Photo of reusable drinking water bottles at a tertiary education institute taken for bacteria content testing.

of the bottles has a capacity of $0.8-1 \mathrm{~L}$ and the material for the bottles is similar to the bottles used by the children of the above test. Testing results showed that the average number of heterotrophic bacteria is $7.5 \times 10^{4}\left( \pm 5.0 \times 10^{4}\right) \mathrm{CFU} / \mathrm{mL}$ and ranged from $4.2 \times 10^{3}$ to $2.4 \times 10^{5} \mathrm{CFU} / \mathrm{mL}$ (Figure 4). Similar to the data from the children of the child care centre, there is a wide range of bacteria content in the bottles and big standard error. There was no bottle with bacteria content less than $500 \mathrm{CFU} / \mathrm{mL}$, since the minimum is $4.2 \times 10^{3} \mathrm{CFU} / \mathrm{mL}$. The average number is more than doubled compared to the bottles used by children, which indicates that the bottles used by tertiary institute's students are less hygienic. Looking at the bottles used by the two groups of people 
(Figures 1 and 3), the higher number of bacteria content in the bottles used by tertiary institute's students is likely due to the bottles having screw caps, which under normal circumstances people will drink directly from the bottle opening (Figure 3). However, the bottles used by children mostly have straws (Figure 1), and children will usually drink from the straws resulting in less direct contact between water in the bottle and the mouth or other possible sources of bacteria. It is believed that most of the bacteria sources responsible for the growth in the bottles is from the direct contact from the mouth. However, the source of bacteria from hand and even air or other sources cannot be excluded.

\section{Impact of bottle users on the bacteria growth in bottles}

To further understand the bacteria content and its growth in the bottles, four new reusable drinking water bottles of a famous brand commonly used by people in Singapore were purchased. The material of the bottle is copolyester with a capacity of 32 ounces $(=0.95 \mathrm{~L})$ and a light grey colour. They were randomly given to four people and water samples were collected for bacteria content testing two days after they have been used. The samples were also collected in the morning which is about 3-4 hours after the bottles being filled up with water. Testing results showed that the average bacteria number is $6.4 \times 10^{4}\left( \pm 4.2 \times 10^{4}\right) \mathrm{CFU} / \mathrm{mL}$ and ranged from $3.7 \times 10^{4}-1.3 \times 10^{5} \mathrm{CFU} /$ $\mathrm{mL}$ (Figure 5). It can be seen that the bacteria content in these bottles used for two days only is similar to those bottles sampled from the tertiary institute's students. Thus, the bacteria can quickly grow in the bottles and bacteria content is high.

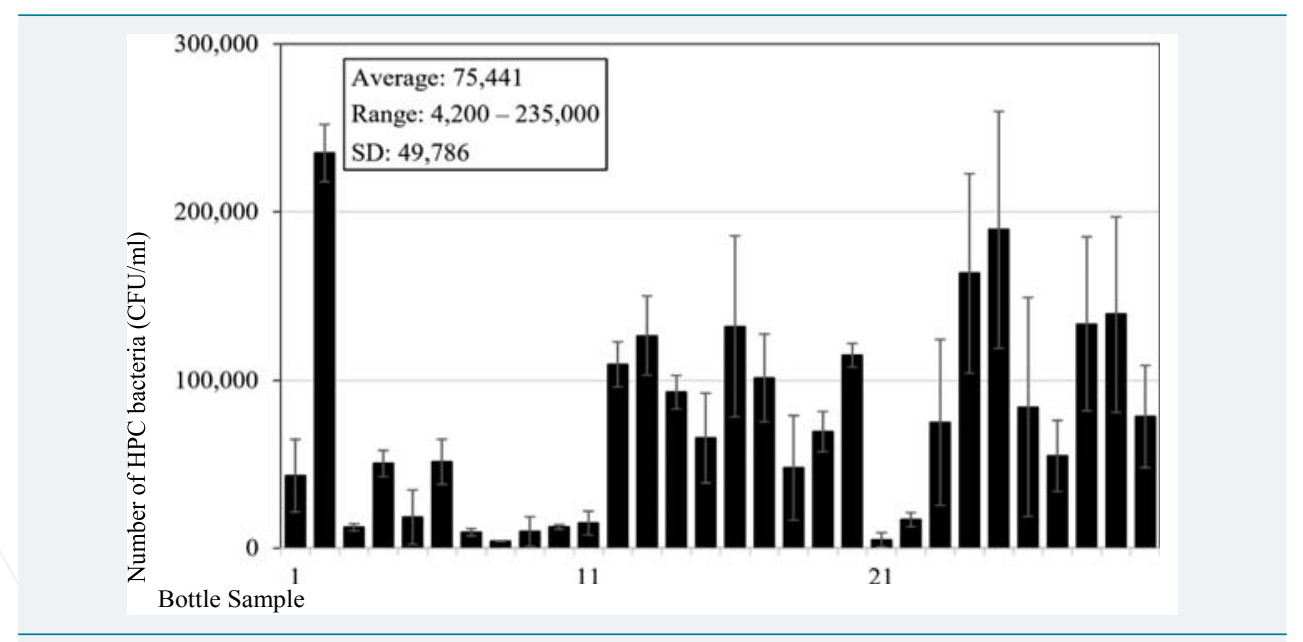

Figure 4: HPC bacteria number in drinking water bottles sampled at a tertiary education institute.

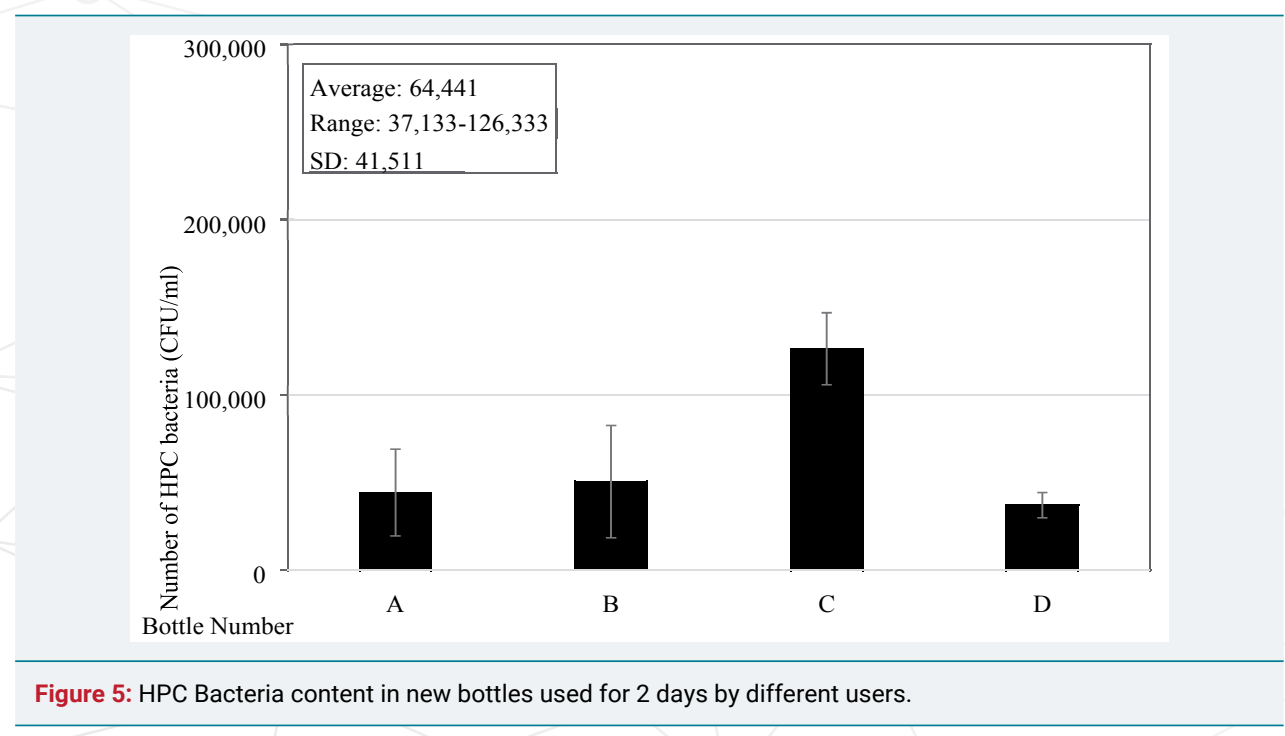




\section{Impact of storage time on the bacteria growth in bottles}

The impact of the storage time in the water bottle on the bacteria growth was tested. A bottle was filled with boiled tap water in the morning at 6:00 AM and it was consumed a few times before sampling at 10:00 AM. The bottle was then left in the airconditioned room at $25^{\circ} \mathrm{C}$ without any further consumption. Sampling was conducted again 6 hours later at 4:00 PM in the afternoon and the following days. Results showed that bacteria number was $8.6 \times 10^{4} \mathrm{CFU} / \mathrm{mL}$ at the first sampling, however it quickly grew to more than double at $1.9 \times 10^{5} \mathrm{CFU} / \mathrm{mL} 6$ hours later (Figure 6). The number of bacteria was slowly decreased to $1.4 \times 10^{5} \mathrm{CFU} / \mathrm{mL}$ one day later, and it further decreased to $9.1 \times 10^{4} \mathrm{CFU} / \mathrm{mL} 30$ hours later, which is similar to the initial number.

Another testing to study the impact of the storage time in the water bottle on the bacteria growth was tested, but this time water was consumed every day to simulate the real consumption from the bottle by normal people. A 32 ounce bottle was used in the testing and a few mouthfuls of water were consumed each time for a few times an hour in day time. A total of four days were tested. The bottle was not left in the airconditioned room, instead that the bottle was carried all the time in the bag with the user, hence the temperature changes depending on weather temperature and whether the user is in an air-conditioned room or outside an air-conditioned room. In general, the temperature should be varied in the range of 20 to $35^{\circ} \mathrm{C}$ in the testing month of Singapore (October). Results showed that initial bacteria number was $2.7 \times 10^{4} \mathrm{CFU} /$ $\mathrm{mL}$. It quickly increased to $1.5 \times 10^{6} \mathrm{CFU} / \mathrm{mL}$ one day later, which is more than 50 times increase (Figure 7). During the following three days, it fluctuated from $9.2 \times 10^{5}$ to $1.7 \times 10^{6} \mathrm{CFU} / \mathrm{mL}$ with a slight increasing trend. It can be seen that the bacteria number in the bottle is very high with an average number around 1.3 million counts per $\mathrm{ml}$ of water if it is consumed all the time by user.

\section{Discussion}

The number of bacteria tested by heterotrophic plate count method showed a very high content from the daily used reusable drinking water bottles. It is in the range from 0 to $2.4 \times 10^{5} \mathrm{CFU} / \mathrm{mL}$ with an average about 34,000 bacteria counts for bottles used by children and about 75,000 bacteria counts for bottles used by adults (Figures 2 and 4). The difference between the two is expected due to the bottle design since most bottles used by children have straws, and there is less chance of direct contact between the water in the bottle and the mouth of the users or other possible bacteria

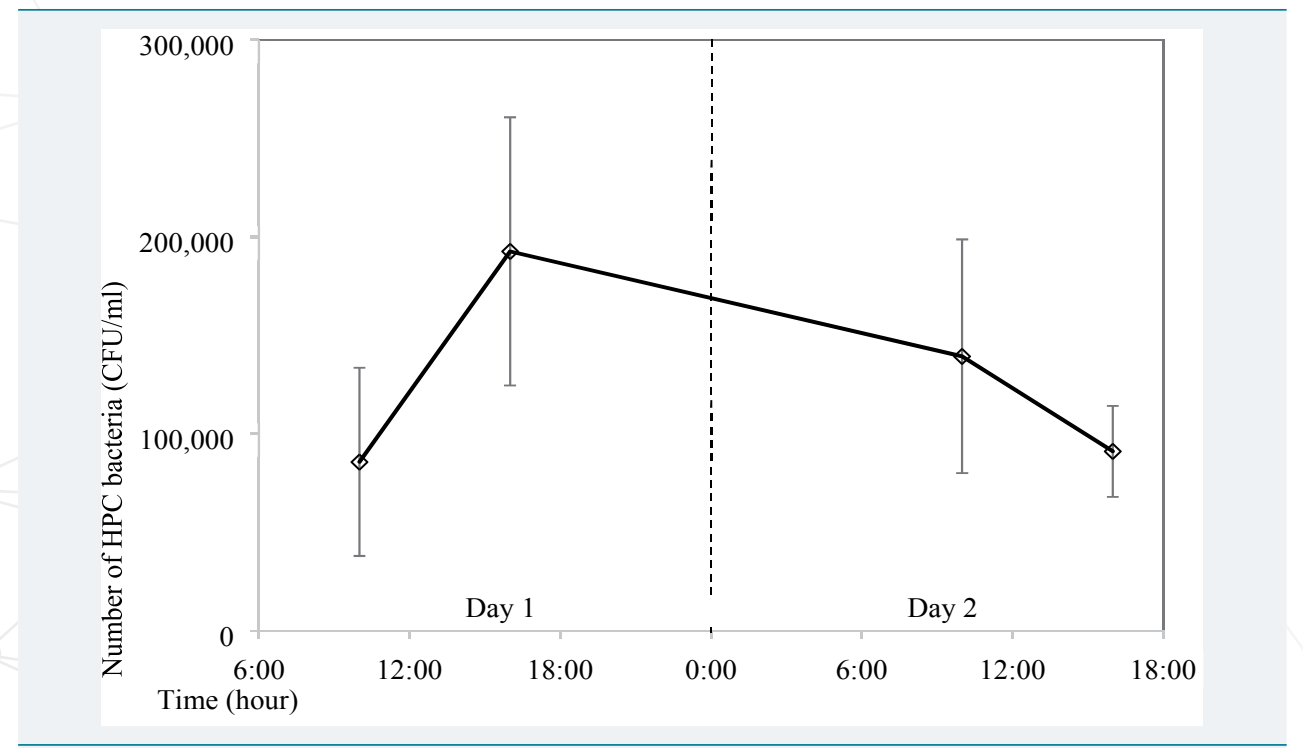

Figure 6: Impact of storage time on HPC bacteria growth (storage of 2 days and water was Consumed only before the first sampling). 


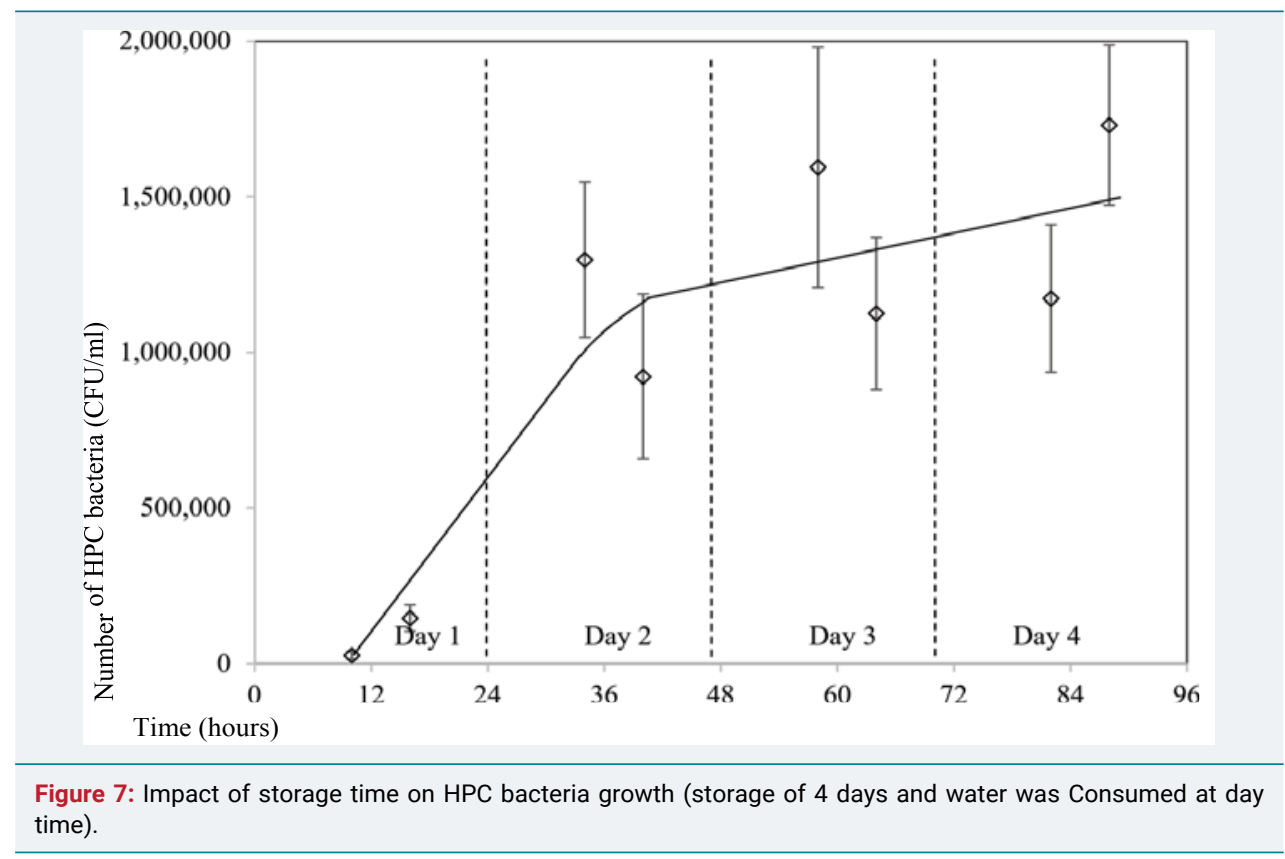

contamination sources. This may lead to a lower bacteria number in the bottles. Among all the sixty bottles sampled, there is only one bottle (2\%) with bacteria number less than $500 \mathrm{CFU} / \mathrm{mL}$. The bacteria number is much higher than those detected in the bottled drinking water which is in the range of $2-150 \mathrm{CFU} / \mathrm{ml}$ [10], but it has a similar level to the bottled natural mineral water after storing for a few days. Gonzalez et al. [17] found that the HPC bacteria can grow to a high concentration of $10^{5}-10^{6} \mathrm{CFU} /$ $\mathrm{ml}$ after three days of storage from the initial $10^{1}-10^{2} \mathrm{CFU} / \mathrm{ml}$ in the source water. It should be noted that bottled natural mineral water normally does not go through the disinfection treatment [9], and this resulted in the high number of bacteria growth in the bottle. However, they also pointed out that no serious outbreaks of infectious illness associated with high concentrations of HPC bacteria in the bottled mineral waters was ever recorded so far.

Heterotrophic plate counting is a procedure used widely by public health laboratories to estimate the bacteria number in water. HPC bacteria are naturally present in all aqueous environments, and they undergo multiplication cycles in drinking water. It is considered a useful general indicator of water quality [18-20,15]. The current standards or guidelines for HPC bacteria in water vary among countries. There is no specific numerical guidelines recommended by World Health Organization for HPC bacteria in drinking water, however, it is suggested that they should be maintained at the lowest level possible [21]. Countries including German, England, Japan and China set HPC bacteria limits of $100 \mathrm{cfu} / \mathrm{ml}$ in the drinking water [21-23], while USA, Canada and Australia have set an acceptable HPC level in the drinking water at less than $500 \mathrm{CFU} / \mathrm{ml}[21,24]$. It can be seen that the recommended HPC bacteria level is normally no more than 100 or $500 \mathrm{CFU} / \mathrm{ml}$ in the drinking water. Although high HPC measurements have not been found to correlate with illness incidence, they do indicate favorable conditions for bacterial growth and potentially the spread of the disease. The HPC bacteria in the reusable drinking water bottles is extremely high comparing with the guidelines by most countries as 100 or $500 \mathrm{CFU} / \mathrm{ml}$. The study also found out that the bacteria number can quickly increase to 1-2 million counts/ $\mathrm{ml}$ one day later if the water in the bottles is consumed all the time as every users do. The analysis of the chlorine content from the water of reusable bottles showed that it only has a free chlorine of $0.01 \mathrm{mg} / \mathrm{L}$ and total chlorine of $0.04 \mathrm{mg} / \mathrm{L}$, but tap water has a free chlorine and total chlorine of 0.18 and $0.58 \mathrm{mg} / \mathrm{L}$ respectively. Low chlorine content in the water of reusable bottles which normally has been boiled reduced the 
chlorine protection for the bacteria growth in the bottles. Considering the extremely high level of HPC bacteria content in the reusable drinking water bottles, some control measures to reduce the bacteria level may be necessary in order to minimize the associated likely health risk of the disease spreading. However, it must be pointed out that this study is still very primitive. There is no testing on the content of Escherichia coli (E. coli), total coliforms, or Pseudomonas aeruginosa in the water bottles, and there is no identification of the bacteria species which will give us a clearer understanding of bacteria diversity and its associated likely health effect. In fact, E. coli is one of the stringent parameters in the WHO drinking water guideline, which states that it must not be detectable in any $100 \mathrm{ml}$ sample [5]. Nevertheless, this study is the first report to show that there is a high level of HPC bacteria content in the reusable drinking water bottles and a more detailed study on the bacteria identification and diversity should be carried out.

\section{Conclusion}

Reusable drinking water bottles are common everywhere to store drinking water for our daily consumption. In this study, it is found that HPC bacteria content is very high in the bottles at a range of $0-2.4 \times 10^{5} \mathrm{CFU} / \mathrm{mL}$ with an average about 34,000 bacteria counts for bottles used by children and about 75,000 bacteria counts for bottles used by adults. The bacteria number can quickly increase to $1-2$ million counts $/ \mathrm{ml}$ in the bottle one day later. Considering the extremely high level of HPC bacteria content in the reusable drinking water bottles, it may be necessary to have some control measures to reduce the bacteria level and to minimize the associated likely health risk of the disease spreading since many people use reusable water bottles every day.

\section{Acknowledgement}

The authors thank Ms Camelia Tay Hui Ying, Sheryl Seah Siew Gek, Mr Ow Jie Ling and Ow Wai Kian from Singapore Polytechnic for their contribution in the project. We are grateful for the financial support from AGplus Technologies and The National Natural Science Foundation of China (NSFC) (U1204207).

\section{References}

1. WHO 2002 The World Health Report 2002-Reducing Risks, Promoting Healthy Life. Geneva World Health Organization. Geneva.

2. Brocklehurst C. The Case for Water and Sanitation. Better Water and Sanitation Make Good Fiscal and Economic Sense and should be Prominent in PRSPs and Budget Allocation. Water and Sanitation Programme-Africa. 2004.

3. WHO, UNICEF. Joint Monitoring Programme for Water Supply and Sanitation. In: Progress on sanitation and drinking-water: 2010 Update. World Health Organization and United Nations Children's Fund. Geneva and New York. 2010.

4. Liu HJ, Tang XS, Liu QS. A novel point-of-use water treatment method by antimicrobial nanosilver textile material. J Water Health. 2014; 12: 670-677. Ref.: https://goo.gl/zHjM9d

5. WHO. Guidelines for drinking-water quality, First Addendum to 4th Edition. World Health Organization, Geneva, 2017.

6. Warburton DW, Peterkin PI, Weiss KF, Johnston MA. Microbiological quality of bottled water sold in Canada. Can J Microbiol. 1986; 32: 891-893. Ref.: https://goo.gl/yBGNva

7. Bischofberger $T$, Cha SK, Schmitt R, König B, Schmidt-Lorenz W. The bacterial flora of noncarbonated, natural mineral water from the springs to reservoir and glass and plastic bottles. Int $\mathrm{J}$ Food Microbiol. 1990; 11: 51-71. Ref.: https://goo.gl/jck5aw

8. Hunter PR. A Review: The microbiology of bottled natural mineral waters. J Appl Bacteriol. 1993 74: 345-352. Ref.: https://goo.gl/Az9qeq

9. Loy $\mathrm{A}$, Beisker $\mathrm{W}$, Meier $\mathrm{H}$. Diversity of bacteria growing in natural mineral water after bottling. Appl Environ Microbiol. 2005; 71: 3624-3632. Ref.: https://goo.gl/ZVHn2q 
10. Oyedeji $\mathrm{O}$, Olutiola PO, Moninuola MA. Microbiological quality of packaged drinking water brands marketed in Ibadan metropolis and Ile-Ife city in South Western Nigeria. Afr J Microbiol Res. 2010; 4: 96-102. Ref.: https://goo.gl/b8xD9C

11. LeChevallier MW. Coliform Regrowth in Drinking Water. J of American Water Works Association. 1990; 82: 74-86. Ref.: https://goo.gl/MVhpcZ

12. Evison L, Sunna N. Microbial Regrowth in House-hold Water Storage Tanks. Journal of American Water Works Association. 2001; 93: 85-94. Ref.: https://goo.gl/JkH2tE

13. Pepper IL, Rusin P, Quintanar DR, Haney C, Josephson KL, et.al. Tracking the concentration of heterotrophic plate count bacteria from the source to the consumer's tap. Int J Food Microbiol. 2004; 92: 289-295. Ref.: https://goo.gl/gzBemb

14. Patrick AS, Roland A, Anani C, Dampare SB. Nutrient-Induced Growth of Coliform and HPC Bacteria in Drinking Water Pipes. J of Env Pro. 2012; 3: 508-517. Ref.: https://goo.gl/2Rp1e4

15. Patrick AS, Roland A. Impact of Temperature on Bacterial Growth and Survival in Drinking-Water Pipes. Res J of Env and Earth Sci. 2012; 4: 807-817. Ref.: https://goo.gl/QrBx4L

16. APHA, AWWA, WEF. Standard Methods for the Examination of Water and Wastewater, 22th ed edited by Rice EW, Baird RB, Eaton AD, Clesceri LS. American Public Health Association. Washington DC. 2012.

17. Gonzalez C, Gutierrez C, Grande T. Bacterial flora in bottled uncarbonated mineral drinking water. Can J Microbiol. 1987; 33: 1120-1125. Ref.: https://goo.gl/xzyq89

18. Manaia CM, Nunes OC, Morais PV, Da Costa MS. Heterotrophic plate counts and the isolation of bacteria from mineral waters on selective and enrichment media. J Appl Bacteriol. 1990; 69: 871876. Ref.: https://goo.gl/ABjykp

19. Tryland I, Fiksdal L. Rapid enzymatic detection of heterotrophic activity of environmental bacteria. Water Sci Tech. 1998; 38: 95-101. Ref.: https://goo.gl/fNN7Rq

20. Leclerc $H$, Moreau A. Microbiological safety of natural mineral water. FEMS Microbiol Rev. 2002 26: 207-222. Ref.: https://goo.gl/LYR7mX

21. Bartram J, Cotruvo J, Exner M, Fricker C, Glasmacher A. Heterotrophic Plate Counts and Drinking water Safety-The Significance of HPCs for Water Quality and Human Health, World Health Organization, NSF International, International Water Association, IWA Publishing. London, UK. 2003.

22. Hambsch B. Distributing groundwater without a disinfectant residual. J Am Water Works Assoc. 1999; 91: 81-85. Ref.: https://goo.gl/JYcgF3

23. Ye B, Yang L, Li Y, Wang W, Li H. Water Sources and Their Protection from the Impact of Microbial Contamination in Rural Areas of Beijing, China. Int J Environ Res Public Health. 2013; 10: 879-891. Ref.: https://goo.gl/823rmo

24. Health Canada. Guidelines for Canadian Drinking Water Quality, 6th edn Minister of Public Works and Government Services Canada, Ottawa, Ontario. 1996. 